\title{
Cross Sectional Study to Determine Apparent Occurrence of Protozoan Parasites in Cross Bred Cattle Inflicting Reproductive Failures
}

\author{
Sravanthi, R. ${ }^{1}$, Jeyabal, L. ${ }^{1 *}$, Srinivasa Rao, K. ${ }^{2}$, Prasada Rao, T. ${ }^{3}$, Gnani Charitha, V. ${ }^{1}$, Sivajothi, S. ${ }^{1}$, \\ Rayulu, V.C. ${ }^{4}$, Suresh Kannan, S. ${ }^{5}$, Nagarajan, K. ${ }^{6}$, Kutty Kumar ${ }^{7}$ and Porteen, K. ${ }^{5}$ \\ ${ }^{1}$ Department of Veterinary Parasitology, College of Veterinary Science, Sri Venkateswara Veterinary University, Proddatur, \\ Andhra Pradesh, INDIA \\ ${ }^{2}$ Animal Husbandry Polytechnic, Sri Venkateswara Veterinary University, Garividi, Andhra Pradesh, INDIA \\ ${ }^{3}$ Department of Veterinary Biochemistry, College of Veterinary Science, Sri Venkateswara Veterinary University, Proddatur, \\ Andhra Pradesh, INDIA \\ ${ }^{4}$ College of Veterinary Science, Garividi, Sri Venkateswara Veterinary University, AndhraPradesh, INDIA \\ ${ }^{5}$ Department of Veterinary Public Health \& Epidemiology, Madras Veterinary College, Chennai, INDIA \\ ${ }^{6}$ Department of Veterinary Pathology, Madras Veterinary College, Chennai, INDIA \\ ${ }^{7}$ Library, College of Veterinary Science, Proddatur, Sri Venkateswara Veterinary University, INDIA \\ *Corresponding author: L. Jeyabal; E-mail: drjeylaksh@gmail.com
}

Received: 11 Feb., 2021

Revised: 10 June, 2021

Accepted: 18 July, 2021

\begin{abstract}
The study was carried out with an aim for detection of protozoan aetiology for infertility in cross bred cattle using conventional and molecular tools in Rayalaseema region, Andhra Pradesh. Blood and cervico-vaginal swabs of 85 crossbred cattle above 3 years of age with and without pyrexia and with the history of infertility/abortion and ten brain, sixteen liver tissue samples of aborted foetuses collected were subjected for the detection of Theileria annulata, Anaplasma marginale, Trypanosoma evansi, Neospora caninum and Tritrichomonas foetus using Giemsa and Acridine orange staining techniques and species specific PCR.The overall prevalence of blood parasites was $17.6 \%$ by Giemsa staining with highest incidence of $T$. annulata $(7.0 \%)$, A. marginale (5.8\%) and T. evansi (4.7\%) where as Acridine orange staining showed $36.4 \%$ with highest prevalence of $T$. annulata (15.2\%), A. marginale (14.1\%) and T. evansi (7.0\%). PCR was standardized for detection of T. annulata, T. evansi and A. marginale, out of 85 blood samples subjected to PCR, $45(52.9 \%)$ were found positive for blood parasites, at $25.8 \%$ (22/85), 20.0\% (17/88) and 7.0\% (6/85) were positive for A. marginale, T. annulata and T. evansi, respectively. The Nested PCR was found to be sensitive than primary PCR in detection of $A$. marginale. Blood parasites prevalence was higher in H.F cross $(58.8 \%)$ and the animals with pyrexia $(68.0 \%)$. The study indicates the marginal role of protozoan parasites in inducing infertility of cross bred cattle.
\end{abstract}

\section{HIGHLIGHTS}

(0 Higher prevalence of A. marginale, T. annulata and T. evansi with infertility and abortions.

( B Blood parasites detection using PCR was more sensitive than conventional methods.

(o Semi-nested PCR was twice more sensitive than primary PCR assay in detection of A. marginale.

Keywords: Infertility, Protozoa, Thileria, Anaplasma, Trypanosoma

Infertility continues to be a major bottleneck in exploiting the fullest production potential of animal wealth and incur an annual loss of more than 500 crore rupees to livestock industry (Pandya, 2007). Indeed, reproductive failure due to abortion is a critical issue in cattle farming
How to cite this article: Sravanthi, R., Jeyabal, L., Srinivasa Rao, K., Prasada Rao, T., Gnani Charitha, V., Sivajothi, S., Rayulu, V.C., Suresh Kannan, S., Nagarajan, K., Kumar, K. and Porteen, K. (2021). Cross Sectional Study to Determine Apparent Occurrence of Protozoan Parasites in Cross Bred Cattle Inflicting Reproductive Failures. J. Anim Res., 11(04): 599-609.

Source of Support: None; Conflict of Interest: None 
with both non-infectious (nutritional, physical, toxic and chemical) and infectious (virus, bacteria, fungus and protozoa) etiologies resulting in pregnancy losses. Though infectious agents by bacterial, viral and fungal origin are perhaps the most frequent cause of abortions in domestic animals (Pretzer, 2008); the significant role of protozoan induced abortion, infertility and repeat breeding could not be neglected (Parkinson et al. 2009). Among the protozoans, Tritrichomonas foetus, Toxoplasma gondii, Neospora caninum, Sarcocystis cruzi, Trypanasoma evansi and Theileria annulata are major organisms, while Anaplasma spp.is found to be the rickettsial causes for infertility in large ruminants (Kaltungo and Musa, 2013). (In recent classification, Anaplasma got classified under gram negative bacteria)

Neospora caninum is an obligate protozoan parasite and was first associated with neuromuscular disease in dogs. It is globally distributed and has been identified as a major cause of infertility in cattle resulting in abortion and infertility. Abortion due to $N$. caninum may occur at any time of gestation but majority happen at 5-6 months period of gestation (Yadav et al., 2016). However, in India neosporosis have not been precisely documented as the occurrence of the disease is very little known. Bovine trichomonosis caused by Tritrichomonas foetus is a sexually transmitted disease leading to abortion, infertility and occasional pyometra. Abortions induced by $T$. foetus occur in the first half of gestation, although a few have been reported in the eighth month of gestation (BonDuran et al., 1994). Out of blood protozoan parasites, Trypanosoma evansi and Theileria annulata were commonly found in cross bred cattle as acute and chronic form. Trypanosoma evansi is widely prevalent in India among different economically important livestock species. The most significant sign of infection in cattle is abortion, which occurs suddenly without any clinical signs in the late stage of pregnancy (Shaapan, 2016). Theileriosis is a tick-borne disease of domestic and wild animals, is one of the most economically devastating diseases of livestock in tropical and subtropical regions (Inci et al., 2007) of the world. It causes economic losses in terms of mortality, morbidity, abortion, infertility and reduced milk yield. Among tickborne diseases, bovine anaplasmosis represents one of the most important diseases of ruminants worldwide. Acute anaplasmosis is characterized by severe anemia, abortion, weight loss, decreased milk production and death (Kocan et al., 2000).
Unlike the reports on the incidence of abortions due to protozoan parasites being available across the globe, the literature pertaining to them is quite scanty from Indian sub-continent. Though India is known to have a high prevalence of protozoan diseases, there were almost no reports establishing them as possible factors for infertility/ abortion in the livestock. Further, a precise estimation of total disease burden pertaining to infertilities has not been fully described among the cross bred cattle of Rayalaseema region, Andhra Pradesh and the long term success in management of these infections could possibly be achieved by thorough understanding about the root cause of abortions and infertilities. Keeping in the view of above, the study was aimed to determine the possible role of various protozoa involved in induction of infertility/ abortion among crossbred cattle of Andhra Pradesh by conventional and molecular confirmation.

\section{MATERIALS AND METHODS}

\section{Examination of cattle}

Total 85 cross bred cattle were examined from different districts and 15 Veterinary Teaching Hospitals of Rayalaseema region, Andhra Pradesh. Before sample collection the details of age, sex and breed of animals and previous history of early abortion, delayed conception, pyometra, vaginitis and infertility were obtained from the farmers. Out of 85 samples, 51 were Holstein Friesian (H.F) cross bred and 34 were Jersey cross bred and the samples were categorized with $(n=60)$ and without $(n=25)$ pyrexia.

\section{Collection of samples}

Blood samples and cervico vaginal swabs of 85 cross bred cattle above three years of age with the history of infertility/ abortion with and without pyrexia were collected. Cervico vaginal swabs and tissue samples (ten brain and sixteen liver tissue samples of aborted foetuses) were collected in Phosphate buffered saline (PBS) and lysis buffer, respectively. Two blood samples were collected from each cattle one from ear vein for preparation of peripheral blood smear and the second one was from jugular vein in EDTA coated blood collection vials for the genomic DNA extraction. 


\section{Sample analysis}

The collected blood samples were examined for detection of blood protozoans by Giemsa staining and Acridine orange (A.O) staining (Ravindran et al., 2007) procedures. Giemsa stained smears were microscopically observed at 100x magnification while the A.O stained smears examined under a fluorescent microscope (Olympus Bx40) when the smear was moist at $100 \mathrm{x}$ magnification. A minimum of 50 fields were screened before declaring negative for the presence of any blood protozoan.

Further, all the collected blood/tissue/cervico vaginal samples were processed individually for molecular diagnosis by extracting DNA using QIAampDNeasy Blood \& Tissue Kit (QIAamp DNA Mini Kit). PCR was standardized for detection of T. annulata, T. evansi and A. marginale, by targeting Tams1 (721 bp), repetitive DNA sequence probe pMUTec 6.258 (227bp) and msp5 (458 bp, $345 \mathrm{bp}$ ) gene, respectively. The targeted gene, primer sequences, product size of various protozoans parasites in the present study are represented in the Table 1 . The amplification was performed in Kyratec (Banglore, India) thermal cycler with the specified cycling conditions as given in Table 2.
Further, semi-nested PCR for Anaplasma marginale was carried out with the internal forward (Amar msp5iF) and external reverse (Amar msp5 eR) primers using $1 \mu \mathrm{l}$ of primary PCR product of the external forward (Amar $\mathrm{msp} 5 \mathrm{eF}$ ) and external reverse (Amar msp5 eR) primers. The product was sequenced, annotated using DNA baser gene Assembler v5.15.0 programme and phylogenetic tree was constructed using phylogenfr programme for the sequenced isolates of $A$. marginale, $T$. annulata and T. evansi.

\section{Statistical analysis}

AMcNemer test was used to assess statistical association between the categorical variables by SPSS 20.0 software. $\mathrm{P}<0.01$ was accepted to be statistically significant.

\section{RESULTS}

In the present study, blood and cervico-vaginal swabs of 85 crossbred cattle (H.F and Jersey $\mathrm{x}$ ) and ten brain and sixteen liver tissue samples of aborted fetuses were screened for the presence of Theileria annulata, Anaplasma marginale, Trypanosoma evansi, Neospora caninum and Tritrichomonas foetus.

Table 1: Oligonucleotide primers used for identification of various protozoan parasites by PCR

\begin{tabular}{|c|c|c|c|c|c|}
\hline Infectious agent & Gene & Primer sequences (5'-3') & $\begin{array}{l}\text { Prod. } \\
\text { Length }\end{array}$ & $\begin{array}{l}\text { Annealing } \\
\text { Temp }\end{array}$ & References \\
\hline $\begin{array}{l}\text { Trypanosoma } \\
\text { evansi }\end{array}$ & $\begin{array}{l}\text { Repetitive sequence } \\
\text { probe pMUTec } 6.258\end{array}$ & $\begin{array}{l}\text { F: TGCAGACGACCTGACGCTACT } \\
\text { R: CTCCTAGAAGCTTCGGTGTCCT }\end{array}$ & 227 bp & $60^{\circ} \mathrm{C}$ & Wuyts et al., 1994 \\
\hline Theileria annulata & Tams 1 & $\begin{array}{l}\text { F: GTAACCTTTAAAAACGT } \\
\text { R: GTTACGAACATGGGTTT }\end{array}$ & $721 \mathrm{bp}$ & $55^{\circ} \mathrm{C}$ & d'Oliveira et al., 1995 \\
\hline $\begin{array}{l}\text { Anaplasma } \\
\text { marginale }\end{array}$ & $\operatorname{msp} 5$ & $\begin{array}{l}\text { eF: GCATAGCCTCCGCGTCTTTC } \\
\text { eR: TCCTCGCCTTGGCCCTCAGA } \\
\text { iF: TACACGTGCCCTACCGAGTTA }\end{array}$ & $\begin{array}{l}458 \text { bp } \\
345 \text { bp }\end{array}$ & $58^{\circ} \mathrm{C}$ & Singh et al., 2012 \\
\hline Neospora caninum & $\mathrm{pNC}-5$ & $\begin{array}{l}\text { F: CCTCCCAATGCGAACGAAA } \\
\text { R: GGGTGAACCGAGGGAGTTG } \\
\text { F: CAGTCAACCTACGTCTTCT }\end{array}$ & $\begin{array}{l}257 \mathrm{bp} \\
156 \mathrm{bp}\end{array}$ & $57^{\circ} \mathrm{C}$ & Baszler et al., 1999 \\
\hline $\begin{array}{l}\text { Tritrichomonas } \\
\text { foetus }\end{array}$ & 5.8S-ITS & $\begin{array}{l}\text { F: CGGGTCTTCCTATATGAGACAGAACC } \\
\text { R: CCTGCCGTTGGATCAGTTTCGTTAA }\end{array}$ & $347 \mathrm{bp}$ & $67^{\circ} \mathrm{C}$ & $\begin{array}{l}\text { BonDurant et al., } \\
2003\end{array}$ \\
\hline
\end{tabular}

Tams - Theileria annulata major merzoite surface antigen, msp -Major surface protein,pNC-5 Neospora caninum specific genomic sequences isolate 5, 5.8S-ITS - 5.8S ribosomal RNA and internal transcribed spacer. 
Table 2: Thermal cyclic conditions

\begin{tabular}{|c|c|c|c|c|c|c|}
\hline Infectious agent & No. of cycles & Intial Denaturation & Denaturation & Annealing Temp & Extension & Final Extension \\
\hline Trypanosoma evansi & 35 & $95^{\circ} \mathrm{C}, 4 \mathrm{~min}$ & $95^{\circ} \mathrm{C}, 1 \mathrm{~min}$ & $60^{\circ} \mathrm{C}, 1 \mathrm{~min}$ & $72^{\circ} \mathrm{C} 1 \mathrm{~min}$ & $72^{\circ} \mathrm{C}, 10 \mathrm{~min}$ \\
\hline Theileria annulata & 30 & $94^{\circ} \mathrm{C}, 5 \mathrm{~min}$ & $94^{\circ} \mathrm{C}, 1 \mathrm{~min}$ & $55^{\circ} \mathrm{C}, 1 \mathrm{~min}$ & $72^{\circ} \mathrm{C} 1 \mathrm{~min}$ & $72^{\circ} \mathrm{C}, 10 \mathrm{~min}$ \\
\hline Anaplasma marginale & 28 & $94^{\circ} \mathrm{C}, 5 \mathrm{~min}$ & $94^{\circ} \mathrm{C}, 1 \mathrm{~min}$ & $58^{\circ} \mathrm{C}, 1 \mathrm{~min}$ & $72^{\circ} \mathrm{C} 1 \mathrm{~min}$ & $72^{\circ} \mathrm{C}, 10 \mathrm{~min}$ \\
\hline Neospora caninum & 35 & $94^{\circ} \mathrm{C}, 5 \mathrm{~min}$ & $95^{\circ} \mathrm{C}, 30 \mathrm{sec}$ & $57^{\circ} \mathrm{C}, 30 \mathrm{sec}$ & $72^{\circ} \mathrm{C} 1 \mathrm{~min}$ & $72^{\circ} \mathrm{C}, 10 \mathrm{~min}$ \\
\hline Tritrichomonas foetus & 30 & $94^{\circ} \mathrm{C}, 5 \mathrm{~min}$ & $94^{\circ} \mathrm{C}, 30 \mathrm{sec}$ & $67^{\circ} \mathrm{C}, 30 \mathrm{sec}$ & $72^{\circ} \mathrm{C} 1.5 \mathrm{~min}$ & $72^{\circ} \mathrm{C}, 1.5 \mathrm{~min}$ \\
\hline
\end{tabular}

Table 3: Blood parasites involved in induction of Infertility/Abortion in crossbred cattle in Rayalaseema region of Andhra Pradesh

\begin{tabular}{|c|c|c|c|c|c|c|c|c|c|}
\hline \multirow{3}{*}{$\begin{array}{l}\text { Total number of } \\
\text { samples }\end{array}$} & \multirow{3}{*}{ Diagnosis method } & \multicolumn{6}{|c|}{ Blood parasitic infections } & \multirow{2}{*}{\multicolumn{2}{|c|}{ Total }} \\
\hline & & \multicolumn{2}{|c|}{ Anaplasma marginale } & \multicolumn{2}{|c|}{ Trypanosoma evansi } & \multicolumn{2}{|c|}{ Theileria annulata } & & \\
\hline & & $\begin{array}{l}\text { No. } \\
\text { Positive }\end{array}$ & $\%$ positive & $\begin{array}{l}\text { No. } \\
\text { Positive }\end{array}$ & \% positive & No. Positive & \% positive & $\begin{array}{l}\text { No. } \\
\text { Positive }\end{array}$ & $\begin{array}{l}\% \\
\text { positive }\end{array}$ \\
\hline \multirow{3}{*}{85} & Giemsa staining & 5 & 5.8 & 4 & 4.7 & 6 & 7.0 & 15 & 17.6 \\
\hline & $\begin{array}{l}\text { Acridine orange } \\
\text { staining }\end{array}$ & 12 & 14.1 & 6 & 7.0 & 13 & 15.2 & 31 & 36.4 \\
\hline & PCR & 22 & 25.8 & 6 & 7.0 & 17 & 20 & 45 & 52.9 \\
\hline
\end{tabular}

Out of 85 blood samples screened, 45 samples (52.9\%) were positive for various blood parasites that could be attributed for inducing infertility/abortions. Among the 45 positive samples, $7.0 \%, 20.0 \%$ and $25.8 \%$ of crossbred cattle were found infected with the T. evansi, T. annulata and $A$. marginale, respectively. Though statistically not significant, incidence of haemoprotozoan infections were higher among H.F cross bred (58.8\%) as compared to Jersey cross bred animals (44.1\%). Results revealed that $28(46.6 \%)$ out of 60 crossbred cattle without the sign of pyrexia were found positive for blood parasites whereas 17 out of 25 cattle with pyrexia signs showed $68.0 \%$ of prevalence for blood parasites.

\section{Staining methods}

The overall prevalence of blood parasites was $17.6 \%$ by Giemsa's staining method. The highest incidence was observed for T. annulata (7.0\%) followed by A. marginale (5.8\%) and T. evansi (4.7\%) (Fig. 1, 2 and 3). Blood smears further examined with A.O staining revealed, a total of 31 blood samples out of 85 were tested positive for blood parasites giving an overall prevalence of $36.4 \%$ (Table 3). Highest prevalence was observed for T. annulata (15.2\%) followed by A. marginale (14.1\%) and T. evansi (7.0\%) (Fig. 4, 5 and 6).

\section{Molecular assays}

The DNA extracted from 85 blood samples were subjected to PCR assay and 45 were detected positive for different blood parasites at 25.8\% (22/85), 20\% (17/85) and $7 \%(6 / 85)$ for $A$. marginale, T. annulata and $T$. evansi, respectively (Table 3 ). However, $N$. caninum and $T$. foetus were not detected from either of the 26 tissues and 85 cervico vaginal contents that were subjected for PCR assay.

The T. evansi specific primers used in the present study amplified the expected amplicon size of 227bp (Plate 1). Theileria annulata identification by PCR was done by gene encoding $30 \mathrm{kDa}$ major merozoite surface protein (Tams1). The amplified PCR product size of $721 \mathrm{bp}$ confirmed the presence of T. annulata in 17 (21.1\%) out of 85 crossbred cattle (Plate 2). Under the molecular survey, more number of $A$. marginale positive cases was encountered. Initially, only 13 positive cases were detected by primary PCR targeting msp5 gene (Plate 3), whereas with the help of semi-nested PCR (Plate 4), 22 samples were confirmed positive for A. marginale.

Phylogenetic tree constructed for sequenced isolates of A. marginale, T. annulata and T.evansi revealed that T. annulata T3 isolate of Ananthapur origin was $100 \%$ identical and the $T$. annulata merozoite surface protein 

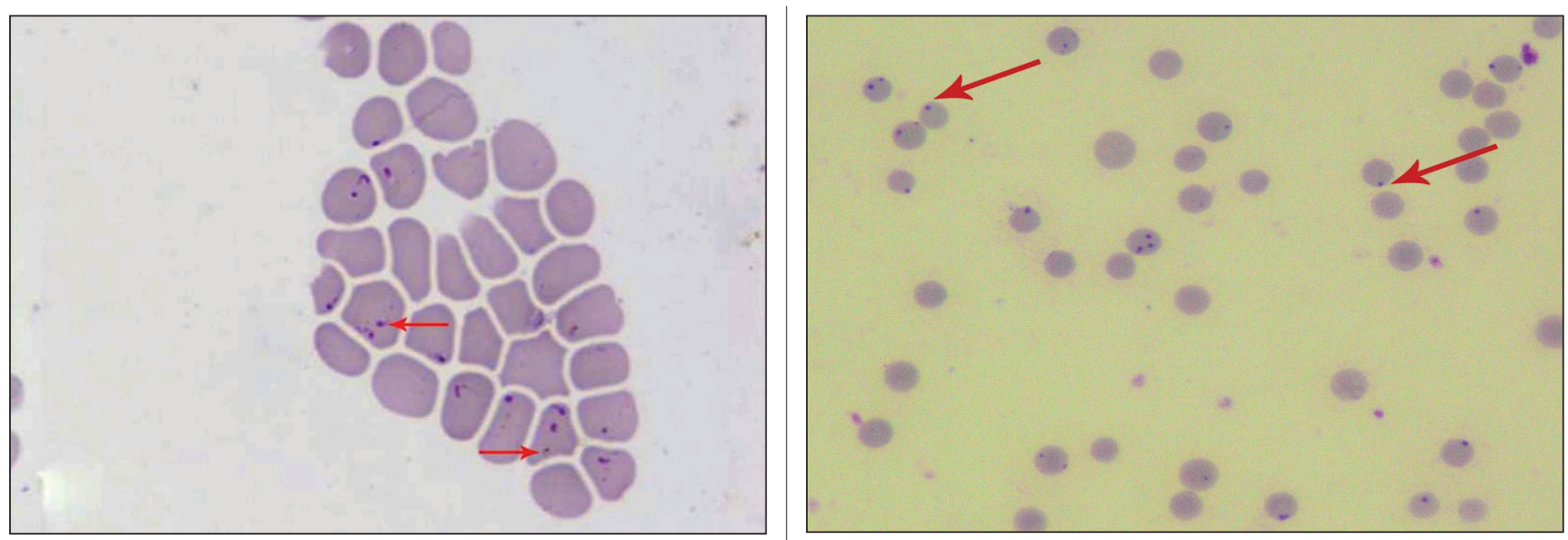

Fig. 1: Intra erythrocytic piroplasms of Theileria annulata in Fig. 2: Giemsa stained blood smear of H.F crossbred cattle Giemsa stained blood smear of H.F crossbred cattle observed revealing the presence of Anaplasma marginale in the RBC, under light microscope (100x)

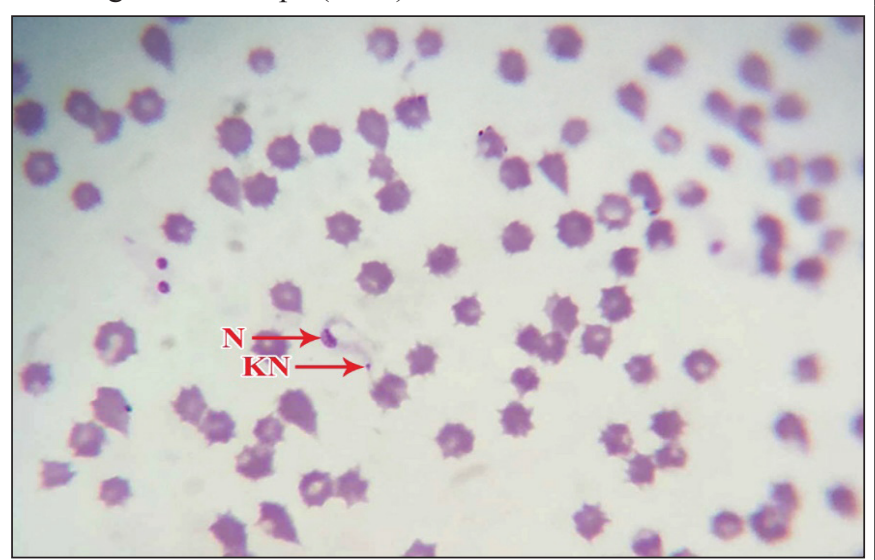
observed under light microscope $(100 x)$

Fig. 3: Trypanosoma evansi in Giemsa stained blood smear of Fig. 4: Intra erythrocytic piroplasms of Theileria annulata in A.O H.F crossbred cattle observed under light microscope (100x). N- stained blood smear of Jersey crossbred cattle observed under Nucleus, KN - Kinetoplst
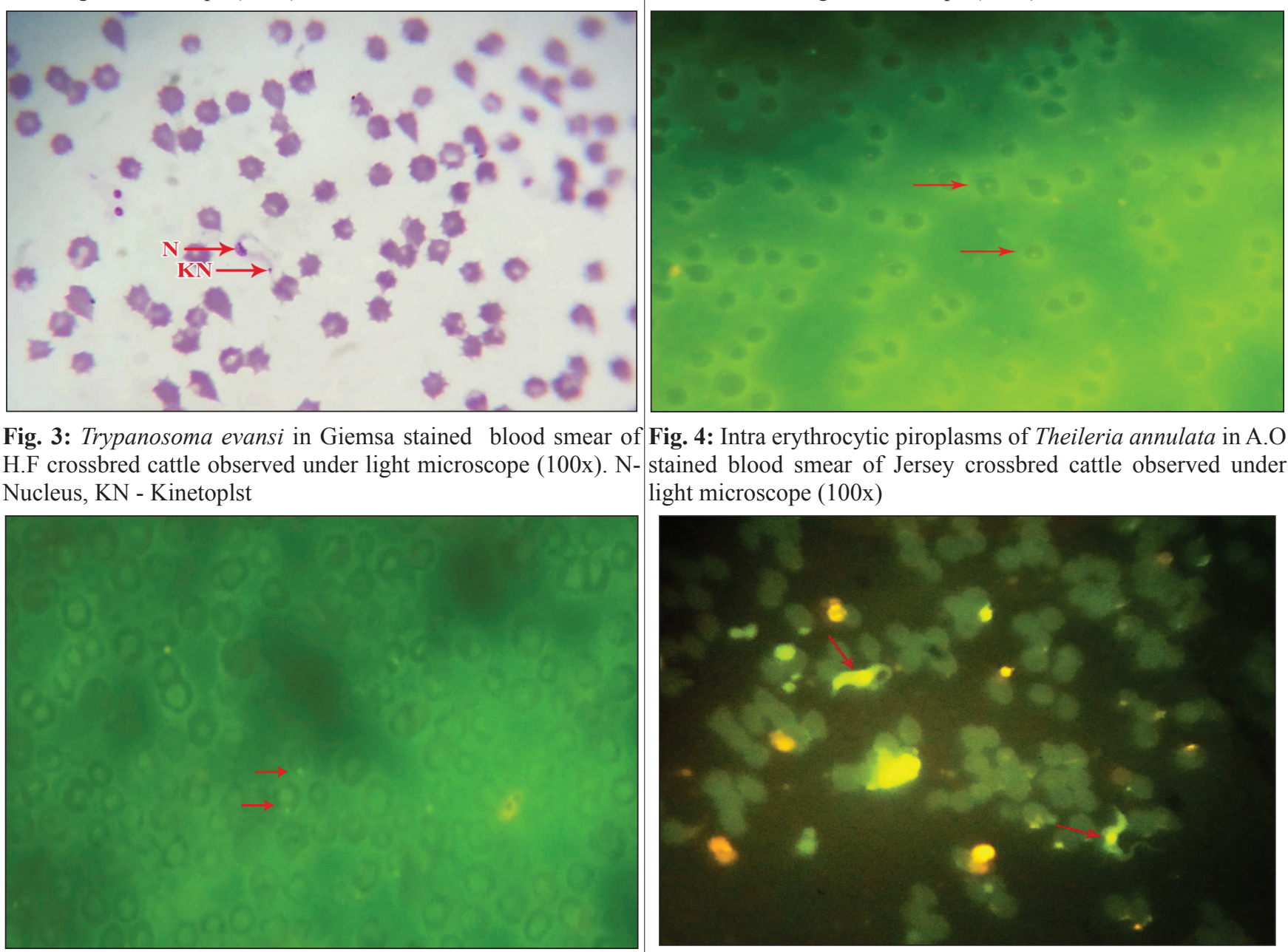
light microscope $(100 \mathrm{x})$

Fig. 5: Fluorescence of Anaplasma marginale is observed in the Fig. 6: Trypanosoma evansi in A.O stained blood smear of H.F margin of RBC of Jersey crossbred cattle (100x)

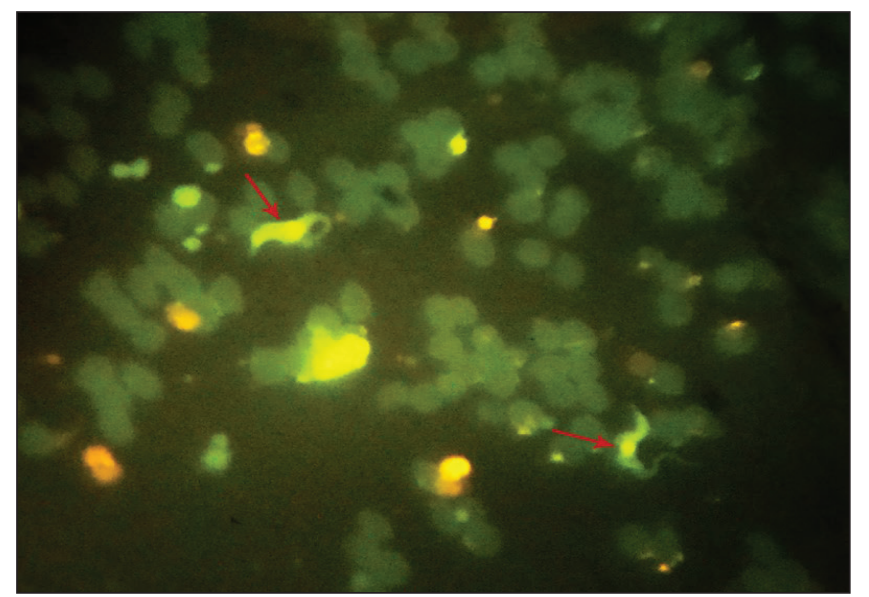

Fig. 6: Trypanosoma evansi in A.O stained blood smear of $\mathrm{H}$.
crossbred cattle observed under fluorescent microscope $(100 \mathrm{x})$ 


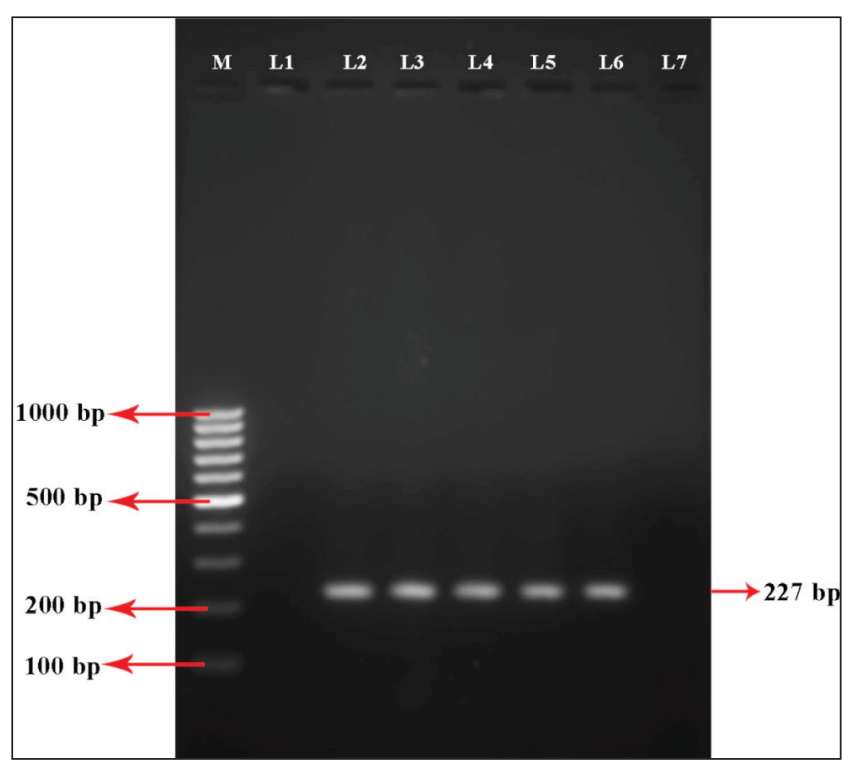

Lane M : 100 bp DNA ladder; Lane $1:$ Non template control; Lane 2, 3, 4, 5, 6: Samples positive for $T$. evansi; Lane 7 : Sample negative for $T$. evansi.

Plate 1: PCR amplification of 227 bp fragment of repetitive sequence probe pMUTec 6.258 of Trypanosoma evansi from blood of cross bred cattle

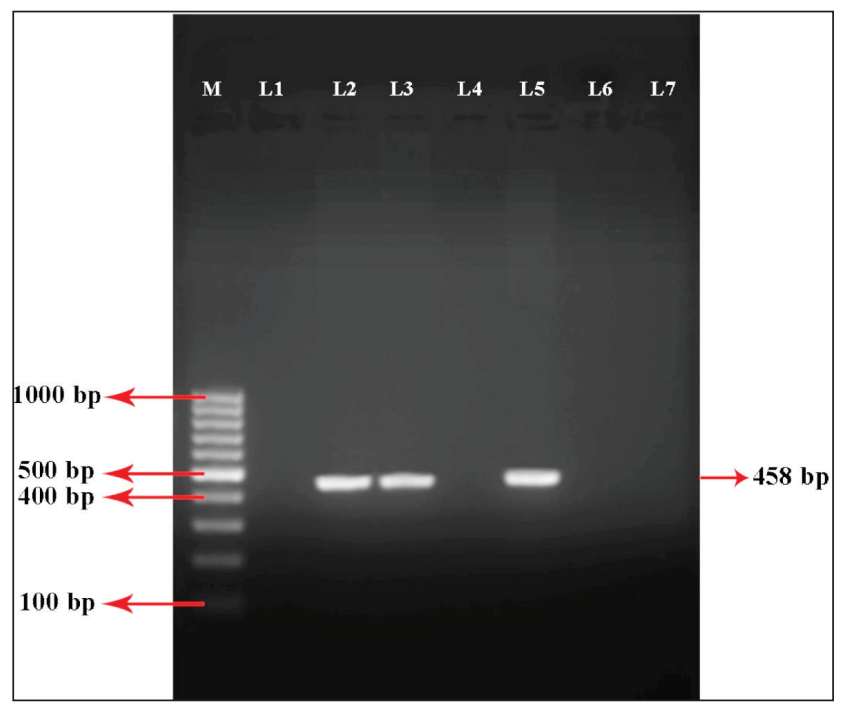

Lane M : 100 bp DNA ladder; Lane 1 : Non template control; Lane 2, 3 : Samples positive for $A$. marginale; Lane 5 : Positive control; Lane 4,6,7 : Samples negative for $A$. marginale.

Plate 3: PCR amplification of $458 \mathrm{bp}$ fragment of major surface protein (msp 5) of Anaplasma marginale

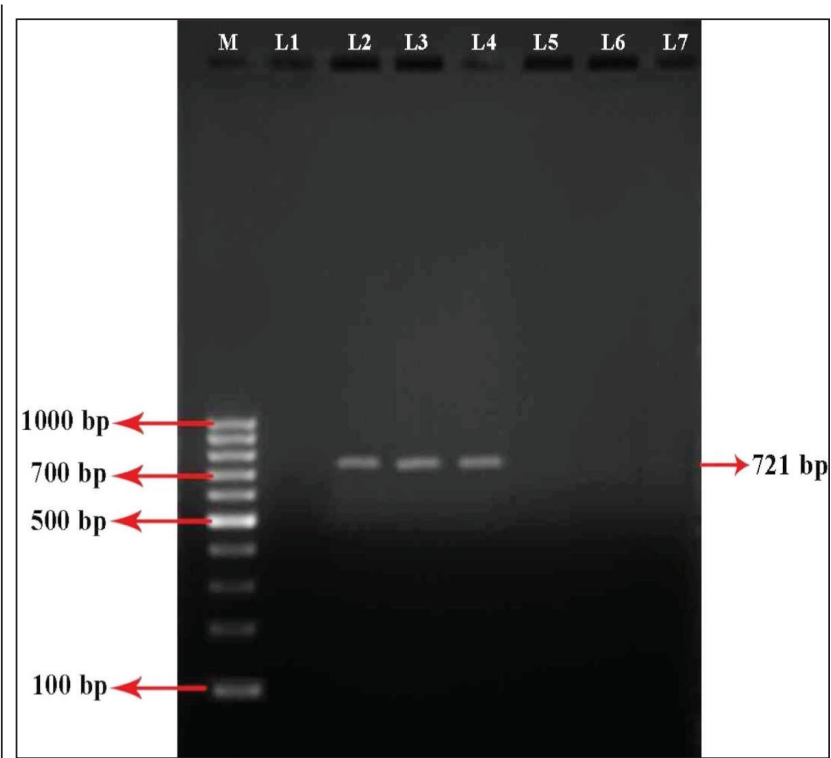

Lane M : 100 bp DNA ladder; Lane 1 : Non template control; Lane 2, 3, 4 : Samples positive for $T$. annulata; Lane 5, 6, 7 : Samples negative for T. annulata

Plate 2: PCR amplification of $721 \mathrm{bp}$ fragment of major merozoite surface antigen (Tams $1,30 \mathrm{kDa})$ of Theileria annulata from blood of crossbred cattle

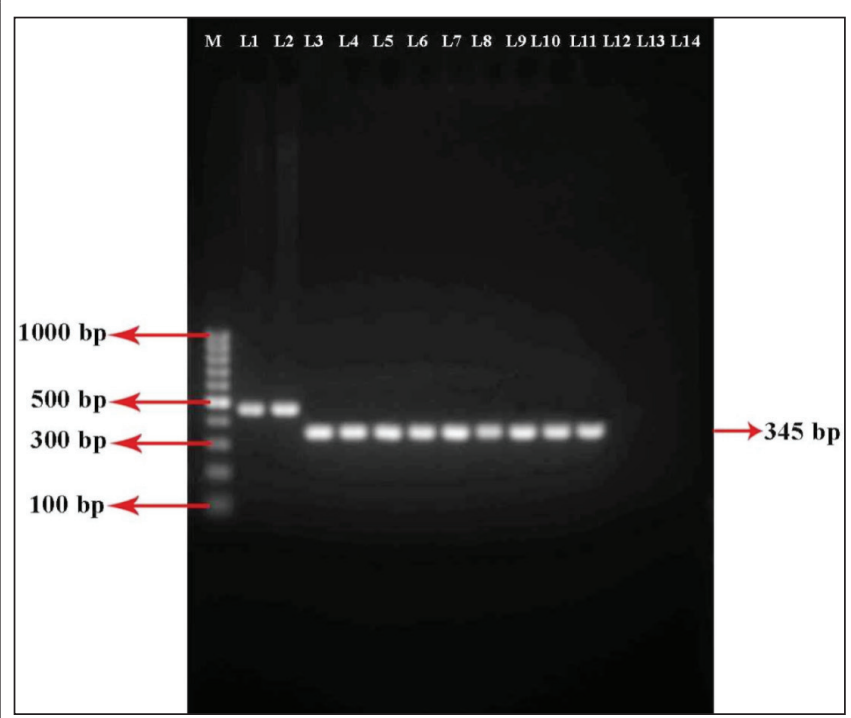

Lane M : 100 bp DNA ladder: Lane1, 2 : Primary PCR product (458 bp) of A.marginale; Lane 3, $4:$ Semi nested PCR of msp 5 gene (458 bp) of A. marginale; Lane 4 to 11 : Semi nested PCR products (458 bp) of $A$. marginale; Lane 12, 13 : Samples negative for $A$. marginale; Lane 14 : Non template control.

Plate 4: Nested PCR amplification of major surface protein (msp 5) of Anaplasma marginale from blood of crossbred cattle 
gene (gene bank accession no KP235484) showed 100\% similarity to IVRI, ICAR Northern region and Tamil Nadu isolate of Indian origin (Fig. 7).

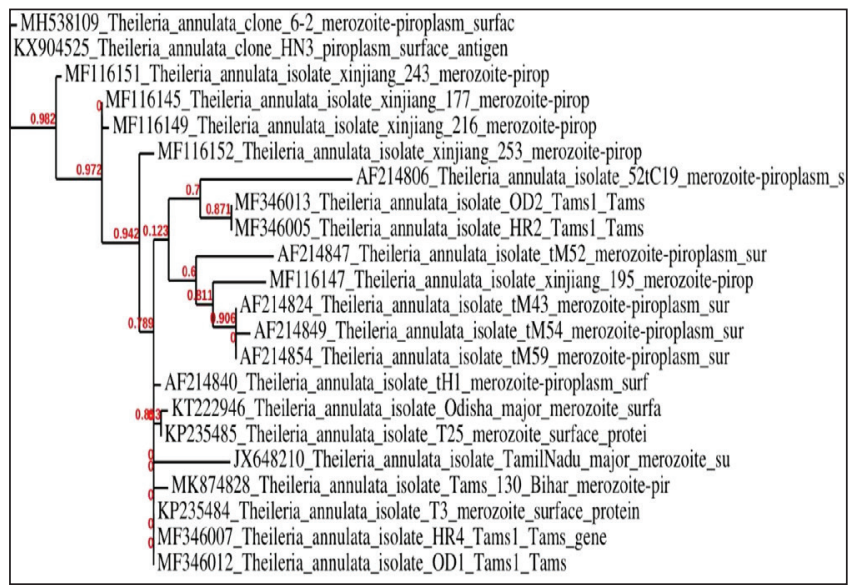

Fig. 7: Theileria annulata phylogenetic analysis

Likewise, T. evansi of Andhra Pradesh region sequence was $100 \%$ identical with VSG protein genes already published in NCBI viz. the accession Nos. MK757490 (south kerala), HM209054 (Israel), JF894242 (UK) ( $T$. evansi) and JQ917146, FN554972 (T. brucei) (Fig. 8).

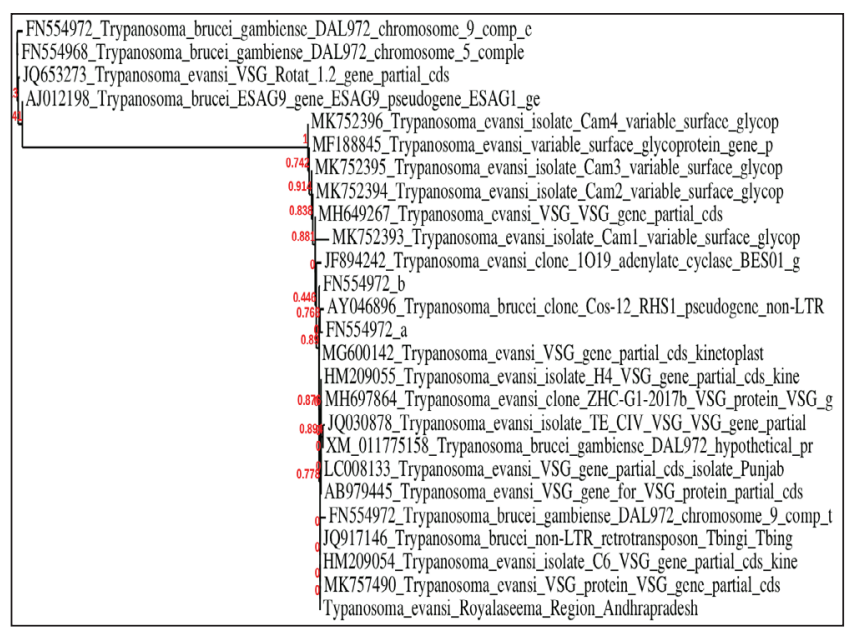

Fig. 8: Trypanasoma evansi phylogenetic analysis

The analysis of the $A$. marginale msp5 Andhra Pradesh gene sequence has got $100 \%$ identity with the published msp5 genes of $A$. marginale in NCBI viz. the Accession Nos.K626208, MK715439 of Muryad Region and MG 676463 of Wayand region (Fig. 9).

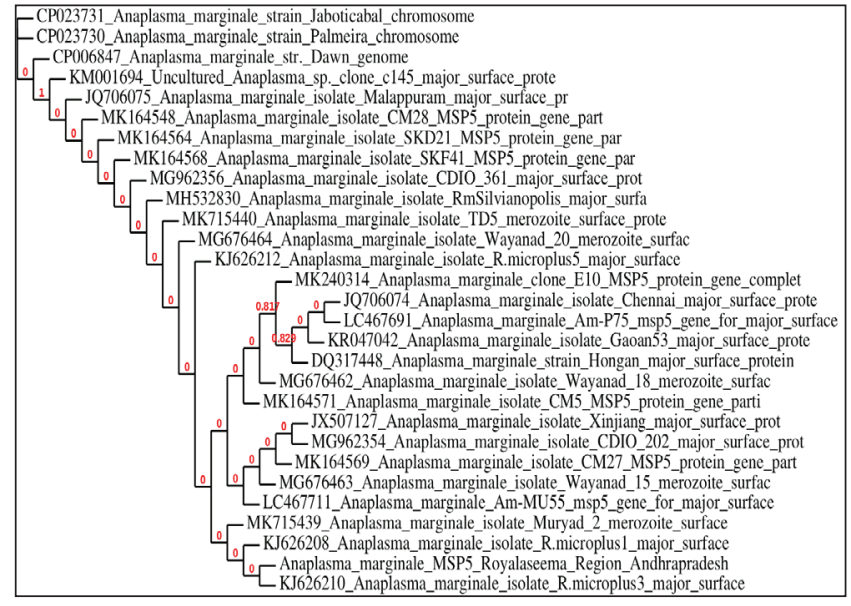

Fig. 9: Anaplasma marginale Phylogenetic analysis

\section{DISCUSSION}

Out of 85 blood samples screened, 45 were found positive for various blood parasites with the prevalence rate of $52.94 \%$. The percent prevalence of blood parasites in the study was found higher than the earlier reports of Jayalakshmi et al. (2019) who observed $14.9 \%$ of haemoprotozoans in cattle, respectively; but lower than the reports of Shashi Kala and Deo (2018), who recorded $74.47 \%$ of prevalence. The difference in percent prevalence might be due to the variations in sample size, regions, season and the method of detection (Jittapalapong et al., 2009). Among 45 positive samples, 25.8\%, 20.0\% and $7.0 \%$ of cross bred cattle were found infected with the A. marginale, T. annulata and T. evansi, respectively and these findings were in concordance with the findings of Jayalakshmi et al. (2019) who reported highest prevalence of anaplasmosis followed by theileriosis and trypanosomosis. Higher prevalence of blood parasites in the present study was in correlation with the availability of its suitable vectors viz. Tabanus, Stomoxys, Rhipicephalus, Boophilus spp. and Hyalomma spp. in the semi-arid region of Andhra Pradesh could be due to the prevailing hot and humid weather and the same was reported by Rajendaran and Hafeez (2003).

Between crossbred cattle, the prevalence of blood parasites were higher among H.F $\times$ cattle $(58.8 \%)$ as compared to Jersey $\times(44.1 \%)$, this finding was in accordance with Velusamy et al. (2014) who reported higher prevalence of haemoprotozoan diseases in H.F and Jersey cross than 
indigenous breed. The higher prevalence of $T$. annulata in H.F (25.5\%) than Jersey (11.7\%) cross bred cattle was also accorded with the findings of Naik et al. (2016), who reported higher prevalence of T. annulata infection in H.F $(29.85 \%)$ followed by Jersey $(23.33 \%)$.

\section{Staining methods}

Through Giemsa's staining, the highest incidence was observed for T. annulata (7.0\%) followed by A. marginale (5.8\%) and $T$. evansi (4.7\%) was in support with the findings of Shashi Kala and Deo (2018) and Maharana et al. (2016), who reported higher prevalence of theileriosis followed by anaplasmosis and trypanosomosis in cattle of Bihar and Haryana states. Microscopic finding of higher prevalence of $T$. annulata than $A$. marginale might be due to the fluctuating nature of $A$. marginale organisms during the course of its pathogenicity. Further it would be difficult to differentiate between Anaplasma organisms and structures like Howell-Jolly bodies, Heinz bodies and other staining artifacts which often commonly encountered during routine blood smear examination. The similar difficulty in screening of Anaplasma organisms through Giemsa's staining was reported by Carelli et al. (2007).

In comparison to Giemsa's staining (17.6\%), AO staining detected $31(36.4 \%)$ positive cases and found to be accurate, simple and rapid for screening large number of blood smears for the detection of haemoprotozoan and rickettsial organisms. Highest prevalence was observed for T. annulata (15.2\%) followed by A. marginale (14.1\%) and T. evansi (7.0\%). Similarly, Nair et al. (2011) in Kerala found $50.0 \%$ positivity of haemoprotozoans on AO staining and $43.33 \%$ positivity with Giemsa's staining in cattle.

\section{Molecular analysis}

The DNA extracted from 85 blood samples were subjected to PCR assay and 45 were detected positive for different blood parasites at 25.8\% (22/85), 20\% (17/85) and $7 \%(6 / 85)$ for A. marginale, T. annulata and $T$. evansi, respectively. However, N. caninum and T. foetus were not been detected from either of the 26 tissues and 85 cervico vaginal contents. In contrast to the present findings, Sengupta et al. (2012) established the seroprevalance of $N$. caninum in India and none of the reports claimed the detection of gDNA of $N$. caninum.
The $T$. evansi specific primers used in the present study amplified the expected amplicon size of $227 \mathrm{bp}$ as previously described by Wuyts et al. (1994). Similar amplicon sizes using similar primers were also obtained by Bal et al. (2014). Theileria annulata identification by PCR was done by gene encoding $30 \mathrm{kDa}$ major merozoite surface protein (Tams1). The amplified PCR product size of $721 \mathrm{bp}$ confirmed the presence of $T$. annulata in 17 $(21.1 \%)$ out of 85 crossbred cattle. Under the molecular survey, more number of $A$. marginale positive cases was encountered with an opinion; Anaplasma could be the major cause in inducing sub clinical infertility/abortion. Initially, only 13 positive cases were detected by primary PCR targeting msp5 gene, whereas with the help of seminested PCR, 22 samples were confirmed positive for $A$. marginale. The result evolved in this study implies that nested PCR was sensitive than primary PCR and these observations were in agreement with Singh et al. (2012), who reported higher prevalence of $A$. marginale infection in semi-nested PCR (73.1\%) than primary PCR (45.2\%) in cattle of Punjab, India. There could be several reasons for the highest prevalence of $A$. marginale than $T$. annulata and T. evansi in crossbred cattle with the history of infertility. To mention few, higher prevalence of $A$. marginale compared to T. annulata and T.evansi could be due to the availability of vast range of vectors viz. hard ticks and other haematophagus insects. Unlike Theileria, the appearance of immunity against re-infection remains poor in $A$. marginale and hence the possibility of reoccurrence of subclinical status of the disease in cattle would prevail commonly in the field. Moreover, higher percentage of A. marginale in PCR could be attributed to the fact that non-descriptive cattle, sheep and goat which acts as a long term carrier to anaplasma and other haemoprotozoans might have acted as a potential source of infection to the crossbred population (Noaman et al., 2009). Further, the latrogenic transmission of anaplasmosis could be attributed due to the routine practice of utilizing the same needle for vaccinating the complete herd (Reinbold et al., 2010). The common occurrence and transmission of sub clinical anaplasmosis via various blood sucking arthropods and contaminated fomites were also recorded by Kocan et al. (2010). Similar reports were documented about the carrier state of A. marginale in cattle by Singh et al. (2012a). The Anaplasma induced abortion could be due to oxygen deprivation, which results in death of foetus (De- Whittier et al., 2007). The PCR method of diagnosis revealed high 
prevalence of hemoprotozoans $(52.9 \%)$ when compared to Giemsa's (7.0\%) and Acridine Orange (20.0\%) staining methods. PCR showed maximum sensitivity in detecting organisms when compared to the conventional staining techniques and these findings were totally in agreement with the earlier reports of Nair et al. (2011).

Phylogenetic analysis revealed T. annulata T3 isolate of Anantapur origin was $100 \%$ identical and the T. annulata merozoite surface protein gene (gene bank accession no KP235484) showed $100 \%$ similarity to IVRI, ICAR Northern region and Tamilnadu isolate of Indian origin. The $100 \%$ similarity of Tams 1 gene between states of India could be due to the exchange of crossbred cattle between various states. Further, due to the adaptation of the scheme on free distribution of cross breed milch cow to the poor farmers, facilitated by the animal husbandry department could act as carriers and the similar strain might propagate and establish between the states. The results in the study are in accordance with the Kumar et al. (2019) who reported the phylogentic analysis of Tams gene and found homologies in the range of $65.8-97.2 \%$ with various isolates across India and abroad. Acharya et al. (2017) reported that Tams-1 gene was having homology with other Indian strains of Andhra Pradesh, Tamil Nadu and Kerala.

In the study, the phylogenetic analysis of the T. evansi of Andhra Pradesh region sequence was 100\% identical with VSG protein genes already published in NCBI viz. the accession Nos. MK757590 (South Kerala), HM209054 (Israel), JF894242 (UK) (T. evansi) and JQ917146, FN554972 (T. brucei). With other sequences compared, a total of 10 clusters with the variation ranging from $0.446 \%$ (AY046896) to $0.914 \%$ MK752395) was recorded and the results were in correlation with previous studies on phylogenetic analysis of $T$. evansi by Elhaig et al. (2018) who reported a significant similarity of $97 \%$ identity with Israel isolate. Devi et al. (2017) reported $100.0 \%$ sequence homologies with all the other known $T$. evansi sequences, viz. buffalo, camel and horseisolates from Karnataka and Bikaner, India (EF495337, JX134605, AB259839); Kenyan isolate (AF317914); camel and cattle isolates from Egypt (JX888091, KF726106), respectively. In contrast to our report Sudan et al. (2017) recorded RoTat 1.2 VSG of $T$. evansi isolate of equine origin with $100 \%$ homology with Egyptiancamel isolate but lesser homology with that of Indian camel and buffalo isolates.
The analysis of the A. marginale msp5 Andhra Pradesh gene sequence has got $100 \%$ identity with the msp5 gene sequence of $A$. marginale in NCBI viz. the Accession Nos.K626208, MK715439 of Muryad Region and MG 676463 of Wayand region. Similarly reports of Moumouni et al. (2015) showed $99.8 \%$ identity of $A$. marginale msp5 sequences [KP347553 and KP347554] with Australia [CP006847], Philippines [AB704328] and China [EF546443] isolates and no appreciable variations in msp5 sequence of $A$. marginale between the different geographical isolates.

\section{CONCLUSION}

The present study identified higher occurence of $A$. marginale, T. annulata and T. evansi in animals with the history of infertility and abortions which can be co-related as a cause. Further the study emphasise that PCR based assay have greater utility when compare to conventional test for screening of these blood parasites. This study also recommends semi nested PCR as an effective tool for the screening of $A$. marginale.

\section{ACKNOWLEDGEMENTS}

The manuscript is the part of Master's thesis submitted to Sri Venkateswara Veterinary University and authors duly acknowledge Sri Venkateswara Veterinary University, Tirupati for providing all necessary facilities to carry out the research work.

\section{REFERENCES}

Acharya, A.P., Panda, S.K. and Prusty, B.K. 2017. Diagnosis and confirmation of Theileria annulata infection in cattle in Odisha, India. J. Entomol. Zool. Stud., 5(4): 1543-1546.

Bal, M.S., Sharma, A., Ashuma, B.B., Kaur, P. and Singla, L.D. 2014. Detection and management of latent infection of Trypanosoma evansi in a cattle herd. Indian J. Anim. Res., 48 : 31-7.

Baszler, T.V., Gay, L.J., Long, M.T. and Mathison, B.A. 1999. Detection by PCR of Neospora caninum in fetal tissues from spontaneous bovine abortions. J. Clin. Microbiol., 37(12): 4059-4064.

BonDurant, R.H., Campero, C.M., Anderson, M.L. and Van Hoosear, K.A. 2003. Detection of Tritrichomonas foetus by polymerase chain reaction in cultured isolates, cervicovaginal 
mucus and formaline fixed tissues from infected heifers and fetuses. J. Vet. Diagn. Invest., 15: 579-584.

Carelli, G., Decaro, N., Lorusso, A., Elia, G., Lorusso, E., Mari, V., Ceci, L. and Buonavoglia, C. 2007. Detection and quantification of Anaplasma marginale DNA in blood samples of cattle by real-time PCR. Vet. Microbiol., 124(12): $107-114$

De-Whittier, D., Currin, N. and Currin, J. 2007. Anaplasmosis in Beef Cattle. Virginia Tech Cooperative Extension, Blacksburg, pp. 400-465.

Devi, A., Shanker, D., Sudan, V., Jaiswal, A. and Singh, A. 2017. Molecular characterization and phylogenetic sequence analysis of unique conserved portion of VSG of Trypanosoma evansi. Ind. J. Anim. Sci., 87(8): 974-976.

D’Oliveira, C., Van der Weide, M., Habela, M.A., Jaquiet, P., and Jongejan, F. 1995. Detection of Theileria annulata in blood samples of carrier cattle by PCR. J. Clinical Microbiol., 33(10): 2665-2669.

Elhaig, M.M. and Sallam, N.H. 2018. Molecular survey and characterization of Trypanosoma evansi in naturally infected camels with suspicion of a Trypanozoon infection in horses by molecular detection in Egypt. Microb. Path., 123: 201205.

Inci, A., Ica, A., Yildirim, A., Vatansever, Z., Cakmak, A., Albasan, H., Cam, Y., Atasever, A., Sariozkan, S. and Duzlu, O. 2007. Economical impact of tropical theileriosis in the Cappadocia region of Turkey. Parasitol. Res., 101(2): 171174.

Jayalakshmi, K., Sasikala, M., Veeraselvam, M., Venkatesan, M., Yogeshpriya, S., Ramkumar, P.K., Selvaraj, P. and Vijayasarathi, M.K. 2019. Prevalence of haemoprotozoan diseases in cattle of Cauvery delta region of Tamil Nadu. $J$. Parasit. Dis., 43(2): 308-312.

Jittapalapong, S., Pinyopanuwat, N., Inpankaew, T., Sangvaranond, A., Phasuk, C., Chimnoi, W., Kengradomkij, C., Kamyingkird, K., Sarataphan, N., Desquesnes, M. and Arunvipas, P. 2009. Prevalence of Trypanosoma evansi infection causing abortion in dairy cows in central Thailand. Kasetsart J., (Nat. Sci.), 43(5): 53-57.

Kaltungo, B.Y. and Musa, I.W. 2013. A review of some protozoan parasites causing infertility in farm animals. ISRN. Trop. Med., 1-6

Kocan, K.M., Blouin, E.F. and Barbet, A.F. 2000. Anaplasmosis control: Past, present and future. Ann. N. Y. Acad. Sci., 916: 501-509.

Kocan, K.M., de la Fuente, J., Blouin, E.F., Coetzee, J.F. and Ewing, S.A. 2010. The natural history of Anaplasma marginale. Vet. Parasitol., 167(2-4): 95-107.
Kumar, S., Shanker, D., Paliwal, S., Sudan, V., Gupta, K. K. and Srivastava, M. 2019. Molecular characterization and sequence phylogenetic studies on Theileria annulata Mathura isolate based on TAMS and $18 \mathrm{~S}$ gene. Ind. J. Anim. Sci., 89(1): 49-52.

Lun, Z.R., Fang, Y., Wang, C.J. and Brun, R. 1993. Trypanosomiasis of domestic animals in China. Parasitol. Today., 9(2): 41-45.

Maharana, B.R., Kumar, B., Prasad, A., Patbandha, T.K., Sudhakar, N.R., Joseph, J.P. and Patel, B.R. 2016. Prevalence and assessment of risk factors for haemoprotozoan infections in cattle and buffaloes of South-West Gujarat, India. Ind. $J$. Anim. Res., 50(5): 733-739.

Moumouni, P.F.A., Aboge, G.O., Terkawi, M.A., Masatani, T., Cao, S., Kamyingkird, K. and Iguchi, A. 2015. Molecular detection and characterization of Babesia bovis, Babesia bigemina, Theileria species and Anaplasma marginale isolated from cattle in Kenya. Parasit. Vect., 8: 1-14.

Naik, B.S., Maiti, S.K. and Raghuvanshi, P.D.S. 2016. Prevalence of tropical theileriosis in cattle in Chhattisgarh state. J. Anim. Res., 6(6): 1043-1045.

Nair, A.S., Ravindran, R., Lakshmanan, B., Kumar, S.S., Tresamol, P.V., Saseendranath, M.R., Senthilvel, K.R.J.R., Rao, J.R., Tewari, A.K. and Ghosh, S. 2011. Haemoprotozoa of cattle in northern Kerala. Ind. Trop. Biomed., 28(1): 68-75.

Noaman, V., Shayan, P. and Amininia, N. 2009. Molecular diagnosis of Anaplasma marginale in carrier cattle. Iran. J. Parasitol., 4(1): 26-33.

Okech, G., Watson, E.D., Luckins, A.G. and Makawiti, D.W. 1996. The effect of experimental infection of boran cattle in early and mid-pregnancy with Trypanosoma vivax. Brit. Vet. J., 152(4): 441-451.

Pandya, A.J. 2007. Dairy science education and training. Dairy India Year Book, $6^{\text {th }}$ edition, pp. 417-421.

Parkinson, T., Arthur, G. H., Noakes, D.E. and Pearson, H. 2009. "Subfertility and infertility" Vet. Reprodn. Obstetrics, 9 ${ }^{\text {th }}$ edition, pp. 476-516.

Pretzer, S.D. 2008. Bacterial and protozoal causes of pregnancy loss in the bitch and queen. Theriogenology, 70(3): 320-326.

Rajendran, C. and Hafeez, M. 2003. Prevalence of ixodid ticks on crossbred cattle in and around Tirupati. J Vet. Parasitol., 17(2): 147-149.

Ravindran, R., Lakshmanan, B., Sreekumar, C., John, L., Gomathinayagam, S., Mishra, A.K., Tewari, A.K. and Rao, J.R. 2007. Acridine orange staining for quick detection of blood parasites. J. Vet. Parasitol., 21(1): 85-86.

Reinbold, J.B., Coetzee, J.F., Hollis, L.C., Nickell, J.S., Riegel, C.M., Christopher, J.A. and Ganta, R.R. 2010. Comparison of 
latrogenic transmission of Anaplasma marginale in Holstein steers via needle and needle-free injection techniques. Am. J. Vet. Res., 71(10): 1178-1188.

Rowlands, G.J., Mulatu, W., Nagda, S.M. and d'Ieteren, G.D.M. 1995. Variations in packed red cell volume and trypanosome prevalence and relationships with reproductive traits in East African Zebu cows exposed to drug-resistant trypanosomes. Act. trop., 59(2), 105-116.

Sengupta, P.P., Balumahendiran, M., Raghavendra, A.G., Honnappa, T.G., Gajendragad, M.R. and Prabhudas, K. 2012. Prevalence of Neospora caninum antibodies in dairy cattle and water buffaloes and associated abortions in the plateau of Southern Peninsular India. Trop. Anim. Hlth. Prod., 45(1): 205-210.

Shaapan, R.M. 2016. The common zoonotic protozoal diseases causing abortion. J. Parasit. Dis., 40(4): 1116-1129.

Shashi Kala. and Deo., B.G. 2018. Prevalence of Haemoprotozoan Disease in Cattle in Rainy Season. Int. J. Cur. Microbiol. Appl. Sci., 7(7): 2693-2699.

Singh, H., Jyoti, Haque, M., Singh, N.K. and Rath, S.S. 2012a. Molecular detection of Anaplasma marginale infection in carrier cattle. Ticks Tick Borne. Dis., 3(1): 55-58.
Sudan, V., Jaiswal, A.K., Shanker, D. and Verma, A.K., 2017. First report of molecular characterization and phylogenetic analysis of RoTat 1.2 VSG of Trypanosoma evansi from equine isolate. Trop. Anim. Health Prod., 49(8): 1793-1796.

Velusami, R., Rani, N., Ponnudurai, G., Harikrishnan, T.J., Anna, T., Arunachalam, K., Senthilvel, K. and Anbarasi, P. 2014. Influence of season, age and breed on prevalence of haemoprotozoan diseases in cattle of Tamil Nadu, India. Vet. World, 7: 574-578.

Wouda, W., Bartels, C.J.M. and Moen, A.R. 1999. Characteristics of Neospora caninum-associated abortion storms in dairy herds in the Netherlands (1995 to 1997). Theriogenology, 52: $233-245$

Wuyts, N., Chokesajjawatee, N. and Panyim, S. 1994. A simplified and highly sensitive detection of Trypanosoma evansi by DNA amplification. SE Asian J. Trop. Med., 25: 266-266.

Yadav, G.P., Manandhar, S., Karna, A.K., Acharya, K.P., Maharjan, D. and Singh, D.K. 2016. Seroprevalence and risk factors associated with Neospora caninum in dairy cattle of Western dairy pocket area in Chitwan District of Nepal. Bangl. J. Vet. Med., 14(2): 215-220. 
